\title{
SOCIAL REALITY AND THE CREATIVE PROJECT OF AN INSULAR CULTURE: CUBA
}

\author{
ALEJANDRO GARCÍA ALVAREZ \\ This paper was first presented by A lejandro García A Ivarez in Spanish and \\ has been translated by $M$ arivic $W$ yndham.
}

$\mathrm{T}$ he enormous development that over more than five centuries has achieved the technologies of land, sea and air transport, together with parallel developments in the field of communications, has facilitated a complex process of cultural exchanges that resolves itself in the concept of transculturation, so widely employed by the Social Sciences and Humanities in Cuba. ${ }^{1}$ This process has not only made possible the generalisation of hegemonic cultures, often shielded in acts of conquest and neocolonial or class-based domination, but it has at the same time helped promote the movements of peoples, habits, customs and beliefs from the economically - and politically - dominated countries to the dominant or at least geographicallydistanced centres.

Cuba is one example in which insularity allowed a defined individualisation within the Caribbean and Latin American ambit in which she finds herself geographically situated. The first three decades of the twentieth century served as an efficient catalyst to the process of strengthening her cultural identity, stemming from what she inherited from her own history, social reality and a fruitful exchange with the outside world.

Many factors have made possible the cultural definition and recognition of Cuba within the international community. This strategic Caribbean island has not only been the recipient of valuable cultural elements imported from other latitudes, as has the whole of Latin America, but it has also formed part of inverse currents taking place for well over five centuries.

\section{THE ARUACO FACTOR}

It is well known that the scarce and culturally rudimentary pre-hispanic population of the Cuban archipelago was left virtually extinct by the violent impact of conquest and cross-breeding. Neither in Cuba, nor in the rest of the Antilles, exist indigenous communities, such as those found in other parts of the American 
continent. Nonetheless, some cultural elements of our ancient population of A ruaco origin have remained fixed in permanent ways in our islands and islets and, at least one of these, managed to transcend with uncommon force its own borders.

Despite the settlements and community-building efforts of the Catholic Church in colonial times, despite the implantations of new names during the period of the Republic, and more especially, despite the changes to the nomenclature based on the names of fallen combatants in the period of the Revolution, the identification of many key places in Cuba rests on an ancient terminology of A ruaco origin, as do also the local zoology and botany. ${ }^{2}$ In this way, Habana, Camaguey, Jatibonico, Bayamo, Baracoa, Guaniguanico, Hanabana, and hundreds of other names embellish with their lyricism the national territory. So do plants such as the corojo, majagua, caoba, yagruma, to name but a few. Animals of different species such as the caimán, almiquí, macabí, guanabá and bibijagua, today retain unaltered their original names.

But the most transcendental element of cubanía of A ruaco origins has been sent to all corners of the world since the seventeenth century, as a form of response by the god of Cohoba or Cohiba to the conquest and colonisation of the islands. The material vehicle of this response has traditionally served to stimulate the relaxation of tensions of daily life and to liberate creative thought in some, as well as to impact dangerously on the health of others. I refer here to the tabaco and particularly to the manufactured product known as the habano. During the seventeenth and eighteenth centuries, the inhabitants of Cuba devoted themselves to planting this leaf in the outskirts of the cities and in the margins of the rivers, thus contributing to the European peopling of the Cuban countryside. Despite this, however, we are neither altogether responsible for the enormous diffusion of its consumption today, nor its principal beneficiaries.

\section{THE DEFINITION OF CULTURAL ELEMENTS SINCE THE ADVENT OF SUGAR}

Throughout the whole nineteenth and twentieth centuries, Cuban society and culture developed under the decisive influence of the sugar crop which, until 1886, had rested on the exploitation of slave labour. Tied to the growth of its production was the stabilising of Spanish immigration and the emergence of the forced migration of Africans, who brought with them not only their skin colour and their labour but also beliefs, customs, rituals and music from diverse origins. The Y oruba, A bakua, A rara y Carbali, all contributed their respective cultures as well as received customs and traditions that had already undergone transculturation in the island.

Overlaying such a varied social and cultural base, the economy of the island, dependent on overseas markets, had given rise to a group of coastal cities which served as centres not only for overseas manufactured goods, but for travellers and publications conveying foreign ideas, customs and beliefs. Arising from these influences and in creative union with the domestic reality, certain basic profiles of Cuban society and culture began to take shape through these centuries. Gifted with great vital force, during the colonial era this insular community attempted at all times to develop its political and economic interests in 
parallel with those which the Spanish metropolis tried to impose by force through its bureaucratic decisions and military control. Due to this permanent contradiction, during the nineteenth century and especially in its second half, separatist ideas achieved great prominence in the Cuban national conscience as a special element of the political culture of the nation.

The neo-colonial option enforced from the time of the US intervention in the War of Independence placed the country on the republican course in 1902, without having first achieved full national self-determination. With Cuba assigned a role complementary to the North American economy as provider of raw sugar, the sugar harvest continued to grow across the island during the first 25 years of the twentieth century, while, at the same time the immigration of labourers, then from the nearby Antilles, picked up in earnest, and the influence of the new metropolis increased throughout capital investments, the control of the domestic market and political pressures over matters internal to the recently founded Republic. In contradiction, there developed over these fragile foundations a most complete maturing of a defined cultural profile of the national character. Here the syncretic and mestizo elements inherent in the ethnic crucible in which Cuban nationality had been forged blended with the most diverse ideas of the critical situation of a society suffering under formally acknowledged external domination. Such reality was captured by the sensitivity of thinkers and artists, as well as by wider sectors of the population. In the cultural expression of the most enlightened exponents of the new era, the cubano blossomed as a manifestation of itself and its distinctiveness; in other cases, it emerged as conscious social critique and, among the most advanced intellectuals and leaders, as an aspiration of changes that might liberate Cuban society from the obstacles imposed on it by neo-colonialism.

\section{ALMOST EVERYTHING CAME WITH THE ADVENT OF SUGAR}

Even though Cuba came to the twentieth century already free from Spanish colonial domination, it remained chained to the political and economic interests of a country more powerful and close: the United States of North America. Since then, there came a change in the intensity and orientation of the Cuban historical process whose basic characteristics were in general terms: an accelerated rise in the production of sugar, the dependency on a buyer's market and at the same time basic provider, the penetration of foreign capital, and the political domination of a new metropolis, different from the pre vious one, not only in those areas related to economic development and political orientation, but also in cultural and social terms.

The War of Independence, concluded in 1898, took a heavy toll on the population of the island, with almost 300000 casualties of the reported dead and a de crease in the population by almost twothirds. The repressive measures of the Spanish military command, and the North American naval blockade at the end of the war, not only decimated the population but also dislocated it, uprooting it from its original places of settlement. The Cuban population at that point was composed of 67.9 per cent whites of Spanish origin, 32.1 per cent blacks and mestizos, composed of Afri- 
cans and their descendants, and 9 per cent foreigners, mainly Spaniards. ${ }^{3}$

Cuban agriculture too arrived at the twentieth-century bearing the scars of the war. An unequal territorial and demographic distribution lent economic advantage to the eastern region in respect of the ancient provinces of Camaguey and Oriente. Some coastal cities, among them the capital of the country, were the dominant economic and political backbone as well as exercising cultural leadership; these were the cities of sugar and commerce. Other centres of particular significance were the capital cities of the provinces which, like Pinar del Rio and Santa Clara, were anchored to agricultural zones linked with the harvest of tobacco and other crops, while Camaguey represented the then debilitated cattle economy of the country.

Transport inside the island developed with the advent of the train in 1837 as a key component of the sugar expansion of the nineteenth century; far from helping to unify the internal market it brought together several regional circles linked to the ports which dealt directly with the international markets. These circumstances contributed to the differentiation between the eastern and western regions of the island, and to maintaining their lack of communication by land. Whatever small exchanges had existed between the regions had taken place until then almost exclusively through the navigation of coastal traffic.

Based on different premises and mercantile deals with the US, Cuban sugar production grew substantially and achieved an accelerated rate during the first twenty-five years of the twentieth century. This allowed the principal industry not only to recover, within a space of only three years, and to achieve pre- war levels, but to multiply five-fold its volume in little more than two decades, which meant a percentage of productive growth of about 20 per cent annually. Tied to the sugar expansion, the public and private railways also grew, extending to the point of reaching land communication across the whole of the national territory. New ports and maritime terminals were created and adapted to modern requirements and to the volume of manipulated merchandise, especially in the case of the provinces of Camaguey and Oriente. But this unforeseen growth brought with it profound deformities. The most significant of these was the reconstitution of the latifundia (large land ownerships). The old farmyards and possessions given as land grants by the Cuban town councils since the sixteenth century had been left demolished almost in their entirety at the start of the twentieth century, even though a few but extensive lands had remained in the form of undivided properties, precisely in those areas not yet penetrated by sugar plantation.

The expansive process of the principal industry also brought changes to the national composition of the population. The migratory flow of the old metropolis was raised so as to later incorporate the importation of labourers of other languages and idiosyncrasies originating from the different islands of the Antilles.

Even though during the first decade of the century the needs of sugarcane agriculture were able to be met with macheteros (machete workers) and unskilled workmen from the eastern region of the island, later expansion of the sugarcane crop to the provinces of Camaguey and Oriente required an increase in the labour force to a measure beyond that available in the country. This situation 
favoured a migration current which, as much from Spain and from The Antilles, remained in place until after $1925 .{ }^{4}$

\section{PAUSESIN THE MODERNISATION OF CUBAN SOCIETY}

As a result of the sugar expansion, the proletarian masses achieved large numbers and superior maturity, in the senses both of organisation and ideology, espe cially during and after the First World War and the emergence of the first socialist state, and this despite the weight of negative factors such as the promotion of the pluri-national migration and the rise of different forms of class repression applied by successive republican governments.

This process of a class development was the direct result of the extension and consolidation of capitalist relations in Cuba within the existing system of domination. As a result of this, and in the same sense as in the previous century, the different sectors of the bourgeoisie established in the Great Antilles were also able to reach new stages in their particular development as a class and to realise some of their aspirations, especially those relating to the broadening of the margin of economic and social benefits designed to satisfy their material and spiritual needs, and in so doing achieve a superior quality of life based on social privilege, comparable to the status of the European and North American bourgeoisie of their time. An example of this can be seen through the urban heritage of La Habana and other cities in the interior of the country, and the existence of valuable collections of universal art put together largely by the domestic bourgeoisie throughout a period of some two centuries and which can be currently found in the National Museum located in the capital of Cuba.

In general terms, the demands of a growing population stimulated both the mercantile enterprises as well as the service industries, thus favouring the broadening of job opportunities for the middle classes and the professional sector, as well as increasing their influence within the framework of the neo-colonial society. These sectors not only grew in numbers, but their cultured expression was able to reflect objectively the social, cultural and political anxieties of the population as a whole.

Despite the economic bonanza, the social inequalities served to produce a polarisation of ideological positions in Cuban society. In it, the deep divisions of class as well as the foreign domination and political corruption were profiled as a triad of permanent misfortunes continually battering the country. To it was added the venality of the governors and the North American intervention in Cuba's internal affairs. ${ }^{5}$

The growth in the production and export of sugar brought with it the transformation of the agro-industrial and mercantile training of the island. The founding and remodelling of the sugar centrales took place at a prodigious rate under the auspices of electrification. The process did not signify at the time the total eradication of the use of steam, but rather the incorporation of a more modern motorised force in the centrales. At the start, the electric plants were meant to give light and energy to certain steps of the industrial process; later this meant the total electrification of the production process.

The rhythms of rural life were imposed upon by the devastating presence of the sugar industry. Compared with 
the miserly earnings of the tobacco and small fruit areas, or with the primitive levels of life imposed on a peasantry marginalised to zones of refuge in swamps and mountains, the sugar plantations and processing centres could be considered splendid and civilised places. But what kind of civilisation was imposed by the exploitation of sugar by the gran central? In the agro-industrial installations founded with the advent of sugar, society was rigidly stratified. Each sector, each social level occupied not only a socially recognised place, but also one physically delineated within the geography of the great plantation and its corresponding urban centre or batey. ${ }^{6}$

In the sugar batey, the Cuban government exercised no jurisdiction whatever until the 1940s. A private police was in charge of maintaining order. Nonetheless, class-based repression in times of social crisis remained always under the control of the National Army, during the direct action of the cavalry corps known as the Rural Guard. The sugar complex composed a factory of several floors, the complicated patio railway and the storage systems, the loading and unloading of the primary railway and of the finished product. Three other important elements completed the basic services at the installation: the grocery or mixed store of the ingenio, the expression of the commercial monopoly exercised by the owners; the chapel, and also the club, almost always for exclusive use. Next to the elevated chimneys of the central could be found the sumptuous palace of the owners. Such was the architectural and technological setting that would make the installations of the colonial batey pale into significance.

To the installation and broadening of new railways destined for public and industrial use was added the construction of new exporting centres, such as Antilla, and the harbour of Nipe, and Pastelillo and Puerto Tarafa in Nuevitas, in addition to an indeterminate number of private ports operated by the sugar companies. New populations such as Florida, Moron, Ciego de Avila and Jatibonico emerged or grew rapidly as a result of the sugar expansion and the transport railways, while the old colonial ports were dredged and their storage and capacities increased.

The modernisation that took place with such impressive speed in the sugar industry also reached, though with some delay, the urban areas. Some cities were given adequate equipment and infrastructure such as electric public systems in place of gas, the construction of sewage systems, all linked to the services of electric trams. Nonetheless, most of the most important towns in the island continued to retain their semblance of colonial times. In this way, La Habana (Havana) was able to exhibit some relevant innovations which captured its somewhat provincial character within the cosmopolitan framework. In La Habana urban development took place especially in the years of the First World War, when the last large tracts of the wall that had enclosed the historic part of the city were brought down, and concluded during the decade of the 1920s and the first critical years of the 1930s. It is to this period that we can date the modernisa tion of the avenues and parks of the capital city, when the littoral zones were filled in, and the streets of La Habana were paved in response to the sudden increase in automobile traffic. Following the electric tram came the mass importation of cars and trucks which, coming from the North American car industry, 
began to take over the streets, particularly in the capital city of the Republic. But the most significant aspect of material progress became apparent through the extension of the limits of the capital city towards the neighbouring municipality of Marianao, old site of hostels and summer homes. In it were formed new residential areas with elegant homes, and based on official plans, other zones were assigned for the construction of houses for the labourers. In this last context, the plans were intended to raise the value of land through the urbanisation of peripheral spaces.

In La Habana as well as in provincial areas were built palaces for the accommodation of clubs and recreational societies of the highest exclusivity. With the creation of these institutions came the new bosses who would dictate the limits of recreational activity and the customs of the comfortable classes, making these the norm of the European-inspired aristocratic forms that had prevailed amongst the members of the bourgeoisie of Hispanic origin, and of forms of conduct apparently more democratic, but fiercely exclusivist, which had been assimilated through the contact ever more intense with North American society of these times.

The consumer power of the comfortable classes in Cuban society allowed the diffusion of patterns representative of the universal culture, especially amongst these sectors and the middle classes in the population, in terms of consumption and enjoyment, not only of material goods of the foreign industry, but also of the polished cultural products originating from Europe and the US. The offer of the cultural product was generally guaranteed by the European theatre and opera companies, concert players of fame, as well as the cinematographic enterprises, European and North American. The great artists of the time and also those with wide popularity, came to the Cuban stages leaving behind stimulating exemplars of professionalism as a contribution to the development of the national art. $^{7}$

\section{A GREAT LEAP IN CULTURAL EXPRESSION}

The national reality in which Cuba found herself in the first three decades of the twentieth century was the result of a process generated by the joint actions of the government of the US, the North American monopolistic companies and their inevitable national allies. Such a reality was caught and reflected by the cultured expression of the country, with an objective image of it forming in the works of its creators. It was precisely since the decade of the 1920s, when a representative sector of the domestic capital, known as the Hispanic-Cuban bourgeoisie, was frustrated in its intentions to achieve a dominant influence over the national economy and politics. At that point the open or covert submission of the Cuban administrations to the interests of the US became more than apparent, as virtually the only guarantee of their stability, a matter recognised by the mass of the people as a fragile experience to which was joined the intervention by North American governments in the internal affairs of the country as common political practices in relation to Cuba.

It was precisely since the worsening of conditions of the Cuban reality, de fined in terms of foreign domination, social injustice, corruption and employment repeated from the repression, that there began with greater force, higher 
degree of maturity and coherence, both the sociological thought as well as the work of the most distinguished artists and intellectuals of Cuba in the first half of the twentieth century. The attempts to redaim the most enlightened of Cuban thought of the previous century were followed by a conscious effort to give that thought continuity and to adapt it to the specific circumstances of each moment. To the tendency often adopted by the intellectuals and artists since the start of the nineteenth century, in terms of promoting the incorporation of modern universal currents of thought and its forms of expression in the area of artistic endeavour as a rejection of the schemes and values bequeathed to the colony, there followed the most diverse efforts to achieve an identification of the cultural components of 'the Cuban', and its creative integration with the purpose of achieving the establishment and interpretation of the most genuine roots of the national identity. ${ }^{8}$

In the first years of the Republic, the basic components of cubania, that is, the Spanish and the African, had been valued separately. Reinforced by a massive immigration of people from the peninsulas, Spanish influence remained anchored to the economic power available to the citizens of the Mother Country since the previous century, as well as by their own institutions, media outlets, the Catholic clergy and an important part of the private educational centres. These factors allowed the maintenance of the values and forms of Iberian culture with singular validity, while the traditional exchange with other values and forms born or assimilated with the sociocultural Cuban experience intensified.

The African component of the national culture had until then been held as a foreign body by the middle classes and the bourgeoisie in society. To the slave origins, the religiosity and the diverse customs, were added as negative element the colour of the skin and, above all, the lack of economic power. All this placed the black population of Cuba during those years, under the banner of discrimination. Religious beliefs as well as dietary habits, customs, music and other basic manifestations of the Afrocuban, were typically considered under the simple denomination of 'the things of the Blacks', and some of its practices were placed at the level of a marginality tinged with crime. It is thus not strange that in 1912 some sectors of the Black population should opt to begin the struggle for their civil rights through their incorporation in an armed movement that would come to be known as Movimiento de los Independientes de Color - the Movement of the Independents of Colour. With the most fierce repression there followed a prohibition for more than 25 years of all those public manifestations of the Black population, such as religious processions, dances, celebration of carnaval and others. As in the European Middle Ages, the accusations of witchcraft and the scandalous processes against the Blacks ensured the completion of the frame of discredit reserved for the Black population at the end of the second decade of the twentieth century. ${ }^{9}$

The search for and the defence of a cultural expression of its own which separated the Hispanic from the African components had led more than a few intellectuals and artists since the nineteenth century to opt for the identification of the genuinely Cuban in the indigenous roots, in the Aruaco, in the manner of the poet of that century, Juan Cristobal Napoles Fajardo, known as El 
Cucalambé. Others had opted for the most absolute rejection of the culture of Hispanic and African origins inherited from the colonial period, in order to formulate the assimilation of other patterns of European culture. There was also the tendency to join the more universal components of Western culture to the criollo tradition of the nineteenth century, such as was achieved to an extent by the composer Eduardo Sanchez de Fuentes. Nonetheless, in the most representative expressions of the plastic, the music and the literature of the decades of the 1920s and 1930s, there were finally expressed in all their richness the components of a culture inherited and decanted, which sank its various roots as much in the past as in the immediate present.

Founded at the University of $\mathrm{Ha}$ vana, the Academia de Bellas Artes of San Alejandro, or in the different academies, conservatoriums and public and private institutions across the island, the Cuban creators of the first three decades of the twentieth century relied on an educational base of considerable magnitude for their professional development. Inheritors of a tradition of cubanía fed secularly by Hispanic and African components, and influenced by contemporary characteristics of the urban and rural habitats of the island, the national intellectuals and artists of that era were also fed by the European and American cultural life which had continued to feed the largest of the Antilles. Cuba, traversed by travellers, was a space open to the influence of personalities and currents which stood out in the art and the politics of that era.

Through the creative connections with overseas, the systematic study, or the lifestyles acquired through residence in the great leading cultural centres, the creators who animated cultural life in those decisive first decades of the twentieth century, received through various channels the sap of the new conceptions and ideas of how to reflect, interpret and transform the reality of life then. This era proved decisive in the maturing of a contemporary Cuban culture. Its legacy was an unrepeatable but coherent grouping of realisations which established the fundamental guidelines for the future development of an expression of what was the national Cuban, and marked it through a language in tune with the times.

\section{THE REFLECTION OF SOCIAL LIFE IN THE CREATORS}

From the very moment of the First N orth American intervention in the island, the romantic verse of the poets of the first republican generation, such as that of Bonifacio Byrne, became a tool for patriotic celebration, at the same time that the reemergence of the modernist theme became a negative critique of colonial values in the works of poets such as $\mathrm{Re}$ gino Boti and Jose M. Poveda. Soaked in cubanía, the poetry of Agustin Acosta became a vehicle of anguish, noncomformity and pessimism before a reality apparently impossible of being transformed by the aspirations for social justice and self-determination of the Cuban people. ${ }^{10}$

It was precisely the critique of the prevailing conditions that became the centre around which resolved other manifestations of the national culture in the first years of the Republic. In a manner similar to the essay of social and political criticism, the novel of the first quarter of the Republic century became a testimony of potent realism which re 
flected the raw realities of the period. The novels of the journalist Jesus Castellanos, as well as those from the labour leader and later academic Carlos Loveira; those of the medical doctor Miguel de Carrion, together with the writings of the sociologist José Antonio Ramos, brought to the understanding of the contemporary reality a great deal more than the apologetic rhetoric or demagogic opposition of the politicians in their speeches and declarations directed to an electorate anxious for change.

The pace of the publications, newspapers and journals rose considerably. From this period dates the foundation (1916) of a frivolous journal, which originated from a transcendent vehicle of cultural propagation. The journal Social had a great deal to do with the bourgeois way of life, but it also served to promote national as well as universal cultural values. Other publications, such as the journal Cuba Contemporánea (1913) created space for analyses and opinions of contemporary issues of the most diverse tendencies, with a high level of specialisation.

Almost at the conclusion of the decade of the 1920s emerged the Revista de A vance (1927). Much influenced by the Spanish Revista de 0 ccidente, this organ of cultural diffusion insisted throughout its brief existence of three years, in the realisation of Cuban thought and of ideas relating to the aesthetic renewal. Mouthpiece of avant-garde thought, Revista de A vance marked an exceptional moment in the history of Cuban culture, characterised by the affirmation of the ability of intellectuals to seek solution to the problems of the country through the efforts of a small group of cultured men and women. ${ }^{11}$ With the end of this publication in 1930 was buried the idealist vision of social progress. Henceforth, this vision was overridden by the reality of the mass struggle against the tyranny of General Gerardo Machado and the neo-colonial system of domination prevailing in the country.

Nonetheless the surge experienced by the organs of cultural diffusion, the profound differences existing in Cuban society, together with the level of illiteracy among the labouring and peasant masses, as well as the incommunication of vast rural zones, meant that wide sectors of society were denied access, not only to the culture, but also to schooling. According to the 1931 census, only 36.5 per cent of the population between the ages of 5 and 9 were able to attend school regularly. 12

While it is true that during the second Republic government (1909-1913) there was an attempt to institutionalise the activities of the intellectuals through the creation of official entities, such as the A cademia Nacional de Artes y Letras and the Academia de la Historia, while the $\mathrm{M}$ useo $\mathrm{N}$ acional also began its precarious existence, ${ }^{13}$ the decade of the 1920 s witnessed a proliferation of private institutions, independent groups and organs of diffusion that emerged as a result of the spontaneous movement of intellectuals and artists who had reached a superior level of maturity and national consciousness. In this context, it is worth mentioning the Sociedad del Folklore Cubano (1923) and the Institución Hispano-Cubana de Cultura (1926) promoted under the direction of the distinguished sociologist and historian Fernando Ortiz. Nonetheless, the supreme manifestation of the work of intellectuals and artists of the decade of the 1920s crystallised in a movement lacking in institutional organisation but bursting with dynamism 
and involvement in the cultural and political life of the country. Born of a combative nucleus of writers who had led a political protest in the ambit of culture in the year 1923, the Grupo M inorista presented a new attitude on the part of artists and intellectuals who openly expressed their discontent with the re publican blemish and, in particular, in respect to the administrative corruption of the government of President Alfredo Zayas. In its endeavours were concre tised as one the love of culture and of revolutionary action. Its program introduced a volume of positions relating to the crisis of Cuban society, while at the same striking against false cultural values, eventually orienting itself towards the search for new perspectives. The minoristas spoke against the distancing of intellectuals from the national political life, urging these to assume positions more actively engaged with the future of the nation. ${ }^{14}$

\section{THE CUBAN IN ARTISTIC EXPRESSION}

The most distinguished painters of the colonial period, Leopoldo Romanach and Armando G. Menocal, undertook from the beginning of the Republic a search for the Cuban through different means; the first, through the landscape and the image centred on the human figure, generally expressive of a kind of social dramatism. In Menocal the epic theme of the War of Independence, of which he was a protagonist, was present particularly in his officially commissioned works. In both cases, we are dealing with pillars of Cuban painting of the first two decades of the century which at the same time were bearers of an academic enterprise of high order, but which did not reach the impressionist forms of the end of the nineteenth century.

Influenced by the same social and cultural circumstances which generated the intellectual works, painting changed considerably its orientation in the decade of the 1920s, attempting to press the Cuban theme and the use of an expression based on avant-garde currents and techniques making their way through Europe and America. Cubism, expressionism, bearers of urban and rural themes while based on Cuban types and personages, began to enrich the national art through the palette and the elegant drawings of Victor Manuel Garcia, or the slippery transparency of Carlos Enriquez. Daily life as a theme was advanced by the fine drawing of Aristides Fernandez, while the cubism of Amelia Pelaez would enter the interior of colonial patios to assume a new plastic dimension. They all gave a new sense to Cuban painting of the 1920s, defining its future orientation. Cuban contemporary painters are the direct descendants of the renewed labour which began to manifest itself in the decade of the 1920s; it is there that resides its coherence as a pictorial movement.

But it was in music where the earliest and most spontaneous expressions of the Spanish and the African were integrated and expressed with greatest force. Perhaps the fact that traditionally the musicians originated from the sector 'of colour' in Cuban society helped to favour the free interpretation of European canonical music, through versions whose rhythm, sensuality and percussion instruments went to play a fundamental role in musical expression. It is precisely music that is the main and perhaps the most popular cultural expression of the Cuban. An example of this is the emergence of the danzón in 1877, which, 
stemming from the widely developed contradanza of the nineteenth century, began during the Republic a nationallyaccepted dance among all social classes. It would not be until the 1920s when, from the eastern-most province, was introduced in the west of Cuba the dancing song popularly known as Son; and which until recent times has enjoyed great popularity across the country as well as overseas. 15 It is in this same way that Cuban musical formulas - old and marineras - have been reflected internationally, as in the case of la habanera, and la guajira, at present well received, especially through the very popular Guantanamera. The sones, guarachas, mambos and the salsa are no longer merely part of Cubans' national heritage but of the wider community in which we live.

A more complex spring in musical creation had as its base the theatre. Originating from a very strong vernacular tradition in Cuban stage, the musical theatre maintained its relevance in the first 30 years of the century, from the theatre 'Al hambra', a burlesque habanero which combined the picaresque with the political critique and the music. Nonetheless, it was not until the end of the decades of the 1920s and beginnings of the 1930s when the genre was able to surpass the ambit of the theatre 'only for men', with the incorporation of young musical figures that would one day be come emblematic such as Ernesto Lecuona, Gonzalo Roig and, later, Rodrigo Prats, who allowed it to escape its narrow margins. The shallow political critique was thus overcome through works of a higher order which claimed the Spanish zarzuela through themes, characters and music truly Cuban. With the launching of 'Niña Rita' in 1927,
Ernesto Lecuona achieved a milestone in Cuban lyrical theatre, 16 with other emblematic works of musical theatre following, such as M aría la 0 , Cecilia V aldés, or EI Cafetal. Thus, in the scheme of these works, the mulata de rumbo became the most relevant character in the island's musical theatre.

With the inauguration of the Republic on 20 May 1902, music had once again entered the course of popular culture, through the performance of concert bands created under the patronage of military regiments and the municipal councils. The colonial urban tradition of the retreta was reclaimed to become a fitting medium for the promotion of music written by the great universally acclaimed composers, amongst the population of the cities and towns. In the case of La Habana, this work was performed by musicians of high reputation and talent, such as Guillermo Tomas and Gonzalo Roig. This activity contributed to the cultivation of musical sensitivity amongst the popular classes. Also, among the elite sectors of the capital there emerged an interest in the promotion of this elevated artistic manifestation. The founding of the Sociedad Pro-Arte Musical in 1916 established an important premise for the later development of concert music in Cuba.

With the aim of promoting symphonic music, two important orchestral institutions were created in the decade of the 1920s in La Habana. In 1922, by the initiative of Gonzalo Roig and with the support of the eminent lbe rian cellist Pablo Casals, was founded the Orquesta Sinfónica Nacional. Two years later, the exclusive Sociedad Pro-Arte Musical signed up the Spanish musician Pedro Sanjuan to found the Orquesta Filarmónica de La Habana. These devel- 
opments worked to promote music in Cuba, by introducing a modern orientation and by promoting contemporary musicians little known in the island, such as Manuel de Falla, Maurice Ravel and Claude Debussy. The introduction of elements of modernity in the music also helped to facilitate access and assimilation of the tambores and Afrocuban rhythms into symphonic music, and which came to be considered as a representative expression of Cuban symphonic music.

The new musical conceptions emerged most clearly through the work of creators such as Amadeo Roldán and Alejandro García Caturla, who marked the start of modern symphonic Cuban art. With the 0 bertura sobre temas cubanos, premiered in 1925, Roldán marked a crucial moment in Cuban music, while talent and formal diversity began to show themselves in Caturla, with Tres danzas cubanas and Rumba (1927), Canto guajiro (1928), and Dos poemas sinfónicos and Bembé (1929). 17

\section{A FEW BRIEF IDEASIN CONCLUSION}

The simultaneous rejection of the colonial legacy and the manifestations of Africanness kept the cultivated expression of Cuban artists and intellectuals away from essential forms and contents until almost the decade of the 1930s, with the almost exclusive exception of popular music. Nonetheless, during the second decade of the century, the negative impact of the imperialist domination on the country had already been felt. It was from this point that a reaction took force among the diverse sectors of the population, which tended towards the rescue and defence of the proper interests and values of the Nation, while at the same time emphasising the lack of perspectives for a practical solution to the fundamental problems of $\mathrm{Cu}$ ban reality within the limits of the system of domination imposed on the country. Problems such as large land ownership and uncontrolled immigration were subjected to the critical judgement of distinguished intellectuals, whilst the North American control over the economy of the island, the discrimination and the cultural penetration, generated negative assessments on the part of those leading most of the national sectors. The critical reflection over such a state of affairs meant that ultimately there arose in the bosom of Cuban society an antiimperialist current of considerable proportions.

Together with their people, the creators forged during the Republic began to express their ideas of rejection to the reality that they had lived, using for their ends both the essay of economic, social and political critique, as well as the language of poetry and the literature of fiction based on the great social realism. In spheres more independent and distant from the social reality, as music and the plastic arts are usually thought to be, this reality also found its appropriate reflection. The cubano began to be expressed with authenticity, mastery and critical sense, thus setting the foundations for future creation.

At the start of the decade of the 1930s, the neocolonial option imposed on Cuba by North America had been achieved in its totality, but at the same time the symptoms of crisis of a system of domination had also been identified and registered, considerably aggravated by the crisis of world capitalism since 1929. A lready by then had been set down the most legitimate values of the national 
culture as the identification of its links with the most universal expressions of the contemporary. The opposition and the rejection of the neocolonial options were the unequivocal symptoms of the degree of consciousness which the Cuban creators and the artists had achieved before the tragic reality which urgently demanded to be transformed.

As much for the maturity and the representativeness of the work achieved, as for the participation in the social life through the groups and organs of dissemination formed by them, the intellectuals and artists of the first 30 years of republican life created the necessary conditions to award successive generations of the most valuable elements of the national tradition, and at the same time communicate to them their modernising urges. The development achieved by Cuban culture to this day owes a special debt to the generations of artists and intellectuals who, during the second and third decades of the twentieth century, gave a significant impulse to the formation of the precious cultural heritage which the Revolution received in January 1959, and which in some form has been carried by the strong emigration which since that date has taken place from the largest island of the Antilles.

\section{ENDNOTES}

1 This novel concept was introduced by the famous Cuban sociologist and historian Don Fernando Ortiz, in order to establish the idea of reciprocal action in cultural exchanges, thus challenging the idea of uni-directional flow attributed to the processes of cultural domination.
2 See M apa Geotopográfico de Cuba by Esteban Pichardo (1859) and A tlas $\mathrm{N}$ acional de Cuba, (1970); also the Diccionario Geográfico, Histórico y Estadístico de la Isla de Cuba by Jacobo de la Pezuela, and Cuba en la M ano, encyclopaedic work about Cuba (La Habana: 1940).

3 Informe sobre el Censo de Cuba 1899, (Washington: Government Press, 1900) pp. 44-45 and 481-484.

4 J. Pérez de la Riva, 'Cuba y la migración antillana 1899-1931', in La República N eocolonial, vol. 2, (La Habana: Editorial de Ciencias Sociales, 1979, tabla VIII-I) and 'Los Recursos Humanos al Comenzar el Siglo', in La República N eocolonial, vol. 1, 1973) p. 44; see also Abel Losada in Cuba, Población y Economía Entre la Independencia y la Revolución, (Universidad de Vigo: Servicio de Publicaciones, 1999) pp. 94 102.

5 In this sensecan be mentioned the US Second Intervention between 1906 and 1909 and the landing of marines in 1912 and 1917. To this can be added the interference of the US President's special agent in Cuba between 1919 and 1923, and the so-called 'mediation' of 1933.

6 Batey is the indigenous term used in Cuba to describe a small settlement, although it is generally used to mean a group of installations, households and spaces surrounding a sugar factory or central. Instituto de Historia de Cuba, La Neocolonia: Reorganización y Crisis, (La Habana: Editora Politica, 1998) pp. 136138; and A. Garcia Alvarez, D ela Consolidación a la Crisis, (La Habana: Editorial Felix Varela, 2001) pp. 85-86 and 98-105.

7 A. García Alvarez, La Gran Burguesía Comercial en Cuba, 1899-1920, (La Habana: Editorial de Ciencias Socialies, 1990) pp. 48-56. 
8 A. García Alvarez, D écadas D efinitorias de la Sociedad y la Cultura en Cuba, 1900-1940, (Revista Arbor: Madrid, julio-agosto de 1991), pp. 204-205; A. Carpentier, La M úsica en Cuba, (La Habana: Editorial Letras Cubanas, 1979) p. 220.

9 For the particular problem of the rights and struggles of the black population, see A. Helg, 0 ur Rightful Share: The A fro.Cuban Struggle for Equality, 1886-1912, (Chapel Hill: The University of North Carolina Press, 1995). A particular case of accusations of witchcraft against Negroes is contained in $\mathrm{E}$. Chávez Alvarez, El Crimen de la Niña Cecilia, (La Habana: Editorial de Ciencias Sociales, 1991).

10 J.A. Portuondo, Bosquejo Histórico de las Letras Cubanas, (La Habana, 1973) p. 46; J. Ibarra Cuesta, N ación y Cultura N acional, (La Habana: Editorial Letras Cubanas, 1981) p. 45.

11 Portuondo, Bosquejo H istórico, and A. Augier, Prosa V aria, (La Habana: Editorial de Letras Cubanas, 1982) pp. 170-171.

12 M emorias Inéditas del Censo de 1931, (La Habana: Editorial de Ciencias Sociales 1978, table 19) p. 252.

13 In Havana, there existed, since the first half of the nineteenth century, a science museum under the auspices of the A cademia de Ciencias Físicas y M atemáticas. Between 1899 and 1900, were founded through private patronage, the museums 'Emilio Bacardi' in Santiago de Cuba and the 'Oscar M. de Rojas' in Cardenas.

14 A. Carpentier, Conferencias, (La Habana: Editorial Letras Cubanas, 1987) p. 140; Roig de E. Leuchsenring, EI Grupo $M$ inorista de Intelectuales y A ristas H abaneros, (La Habana: Oficina del Historiador de la Ciudad, 1961) p. 17; A. Cairo, El Grupo M inorista y su Tiempo, (La Habana, Editorial de Ciencias Sociales, 1979) pp. 49-50.
15 A. García A lvarez, D écadas D efinatorias, pp. 210-211; A. Carpentier, Conferencias, pp. 122 and 188; H. Orovio, Diccionario de la M úsica Cubana, (La Habana: Editorial Letras Cubanas, 1981) p. 379.

16 E. Robreño, Como lo Pienso lo Digo, (La Habana: Editorial Unión, 1985) p. 172.

17 Orovio, Diccionario de la M úsica Cubana, pp. 162, 351; A. García Alvarez, D écadas D efinatorias, pp. 211-213, and 'Cuba en la Mano', Enciclopedia Popular Ilustrada, (La Habana: U car, García y Cía) p. 1004. 